\title{
COMMENT
}

\section{WHAT PROCESS IS DUE? \\ UNACCOMPANIED MINORS' RIGHTS TO DEPORTATION HEARINGS}

\author{
IRENE SCHARF* \\ AND CHRISTINE HeSS**
}

Thousands of foreign-born children enter the United States every year. Many, particularly those crossing at the Mexican border, arrive without legal immigration status and unacconipanied by adults. Once here, these children have certain rights under the Constitution and the innnigration laws of this country. Their primary right is to a deportation hearing. Under the current procedures used by the Immigration and Naturalization Service (INS), however, these children are encouraged to waive that right and "elect" voluntary departure. The voluntary departure process requires that they adnit to having entered the country illegally, choose the country to which they will return, and leave without having had any hearing. ${ }^{1}$ If the children are Mexican, as most are, they spend a short time in a "staging facility" before they are quickly returned to their honieland. If they coine from a country that is not contignous with the United States, however, they are transferred to a long-term facility, where they remain until transportation is arranged back to their home country. ${ }^{2}$

\footnotetext{
* Adjunct Professor and Instructor of Law, University of Puget Sound School of Law.

** J.D., University of Puget Sound School of Law; clerk for the Alaska Supreme Court, 19881989.

The authors would like to thank Deborah Anker for her helpful comments on an earlier draft, and especially Jama Lazerow for his invaluable editorial assistance throughout the progress of this comment.

1. See Nunez v. Boldin, 537 F. Supp. 578, 585 (S.D. Tex.), appeal dismissed, 692 F.2d 755 (5tlı Cir. 1982).

2. Telephone interview with Ms. Chris Davis of the San Diego Sector Border Patrol of the INS (May 26, 1987) [hereinafter INS Interview].

While detained, these children are refused contact with the outside. In recent testimony, it was revealed that

[one child], seven years old, was held at a detention center for nearly six weeks: she did not contact counsel, nor did she receive INS assistance to secure a representative to aid her. [Another child], twelve years old when arrested and detained by agents, remained in custody for more than two weeks without contact with counsel or a representative from the mexiean or salvadoran [sic] consulate. He testified that he did not understand the forms
} 
Denying deportation hearings to unaccompanied minors is a significant problem. From July through September 1987, 2190 juveniles (17 years old and younger) were apprehended by the INS in the San Diego sector alone. ${ }^{3}$ Of those 2190,1827 , or $83.4 \%$, were unaccompanied. ${ }^{4}$ After bemg "processed" by INS officials, 1868 of these minors, or $85.3 \%$, voluntarily returned to their home country, while only 121 , or $5 \%$, asked for a hearing. 5

A waiver of the right to a deportation hearing must be knowing, voluntary, and imtelligent; ${ }^{6}$ otherwise, the waiver is invalid. Without the advice of counsel, illiterate in the Enghish language, often deined adequate translation, and ignorant of American culture and its judicial system, unaccompanied minor aliens cannot knowingly, voluntarily, or intelligently waive their right to a deportation hearing. ${ }^{7}$ Mandatory deportation hearings therefore are essential to protect these children's rights.

presented to him or the significance of the volunteer attorney list; agents did not explain the forms. [The questioning agent] stated that it was not his practice to contact the consulate of a minor ...., nor was he aware of different INS procedures for processing children below 14 years, or between the ages of 14 to 16 .

Post-Trial Brief of Plaintiffs at 15, Perez-Funez v. INS, 619 F. Supp. 656 (C.D. Cal. 1985) (No. 811457) [hereinafter Plaintiffs' Brief].

The effeets of isolation for these young children are exacerbated by attempts to himit their use of the telephone. One 15-year old child "was kept four days in detention without being allowed access to a phone," while another "requested to make a phone call before signing the papers and several times afterward, and was denied." Id. at 23. Yet another minor alien "was held incommunicado for six days in a detention roon for minors ... despite the fact that he and nost of the other thirty detainees would routinely ask the gnards to telephone whenever the cell door was opened." Id. at 24.

3. Known as the busiest section in the nation, the San Diego Sector covers the ten to fifteen mile California-Mexico border near Tijuana. INS Interview, supra note 2.

4. There were 1653 Mexican children and 174 children from other countries (approximately $75 \%$ of the non-Mexican children were from El Salvador). Id.

5. Id.

6. Orantes-Hernandez v. Snith, 541 F. Supp. 351,374 n.27 (C.D. Cal. 1982) (reiterating necessary coniponents of waiver as matter of federal constitutional law).

7. The nature of the "voluntary" departure procedure suggests the nonvolitional character of the ninors' decisions. For example, in recent testimony

several children stated that INS agents sinıply provided the advisal [of their rights and the necessary] fornis and directed then to sign theni; they testified that by virtue of the agents' authority and instrnction, they had no choice, neaningful or otherwise. Sonte . . . asked agents specific questions regarding their rights and were either provided incorrect information or were ignored. [One child] testified that she was given the advisal, but that the processing agent said he was in a hurry. Several other children ... . testified that the agents were talking to them in loud, stern voices, were acting inipatient, upset, or angry, and that as a consequence, each felt afraid to ask any questions. Sonve of the witnesses . . . stated that agents continued questioning them though they cried throughout the interrogation.

Plaintiffs' Brief, supra note 2, at 8-9. 


\section{LEgAL BACKGROUND}

While it is a nation's fundamental right to exclude or admit foreigners, ${ }^{8}$ once they are inside the United States, whether legally or not, they are entitled to the guarantees of the fifth amendnient's due process clause.9 These guarantees protect against denial of life, hiberty, or property without "due process of law."10 "It is well-settled that the right to a deportation hearing is of constitutional scope because deportation involves issues basic to hunian hberty and happiness and, in the present upheavals in lands to which ahens nay be returned, perhaps to life itself." "11 Indeed, the Suprenie Court has noted that "ahens who have once passed through our gates, even illegally, niay be expelled only after proceedings conforming to traditional standards of fairness enconipassed in due process of law." 12

Clearly, then, these children are entitled to due process. But, "what process is due?"13 Due process is a flexible concept, requiring different procedures in different contexts. ${ }^{14}$ Outside the deportation setting, the Suprenie Court has established that "[a] fundaniental requirenient of due process is 'the opportunity to be heard." "15 Additionally, such opportunity "1nust be granted at a meaningful time and in a meaningful nianner."16 Expanding on this concept, lower courts have ruled that, to satisfy due process, the exercise of a right that was created to protect constitutional entitlements--such as a deportation hearing-must be feasible. ${ }^{17}$

More specific requirements for deportation hearings have been established by the Immigration and Nationality Act (the Act). ${ }^{18}$ Under the Act, deportability nuust be established at a hearing for which the ahen has had reasonable opportunity to be present and reasonable notice of the charges. ${ }^{19}$ At the hearing, the alien is entitled to be represented by coun-

8. Galvan v. Press, 347 U.S. 522, 530-31 (1954); Harisiades v. Shaughnessy, 342 U.S. 580, 588-89 (1952); Augustin v. Sava, 735 F.2d 32, 36 (2d Cir. 1984).

9. Mathews v. Diaz, 426 U.S. 67,77 (1976).

10. U.S. ConsT. amend. V.

11. Orantes-Hernandez v. Smith, 541 F. Supp. 351,377 n.32 (C.D. Cal. 1982) (quoting Wong Yang Sung v. McGrath, 339 U.S. 33, 50 (1950)).

12. Shaughnessy v. United States ex rel. Mezei, 345 U.S. 206, 212 (1953).

13. Morrissey v. Brewer, 408 U.S. 471, 481 (1972).

14. Id.

15. Armstrong v. Manzo, 380 U.S. 545, 552 (1965) (quoting Grannis v. Ordean, 234 U.S. 385, 394 (1914)).

16. Id. at 552 .

17. See, e.g., Haitian Refugee Center v. Smith, 676 F.2d 1023, 1039 (5th Cir. Unit B 1982). For a discussion of Haitian Refugee Center, see infra notes 27-34 and accompanying text.

18. Immigration and Nationality Act, $\S 242$ (b), 8 U.S.C. $\S 1252$ (b) (1982) [hereinafter INA].

19. Id. § 242(b)(1), 8 U.S.C. § 1252(b)(1). 
sel, present evidence, cross examine witnesses, and examine and object to evidence offered by the Justice Departinent's attorney (in effect, the prosecutor). ${ }^{20}$ Federal regulations additionally require that the proceedings and documents presented in a foreign language will be accurately translated, and that the immigration judge inform the alien of available procedural rights and free legal services. ${ }^{21}$

Because Congress and the courts have recognized these due process rights for aliens, it follows that the waiver of these rights should be accorded equally stringent regard. ${ }^{22}$ This Comment argues that deportation hearings may not be waived by unaccompamied minor aliens; due process in this context demands mandatory deportation hearings.

\section{What Process is Due to Unaccompanied Minor Aliens?}

\section{A. Denial of Liberty and Property Interests.}

In deportation cases, when INS procedures threaten a life, liberty, or property interest as envisioned by the fiftl amendinent, a constitutionally-recognized interest is at stake and the foreigner is entitled to due process protections. ${ }^{23}$ These protections are triggered when unaccompanied mimor aliens are asked to sigu voluntary departure forms; the current INS procedures used in processing these children not only threaten, but truly deny them both their liberty and property interests. ${ }^{24}$

The liberty interest that exists in a foreigner's right to remain in the United States was recoguized as early as 1903 in the Japanese Immigrant Case:25

20. Id. $\S \S 242(\mathrm{~b})(2),(3), 8$ U.S.C. $\$ \S 1252(\mathrm{~b})(2),(3)$.

21. 8 C.F.R. $\$ \S 242.12, .16$ (a) (1987).

22. See Orantes-Hernandez v. Smith, 541 F. Supp. 351, 376-77 (C.D. Cal. 1982).

23. Cf. Morrissey v. Brewer, 408 U.S. $471,481-90$ (1972) (analyzing the nature of procedures due individuals involved in parole revocation); Board of Regents v. Roth, 408 U.S. 564, 570-72 (1972) (discussing "liberty" and "property" interests as triggering devices for due process requirements under the fourteenth amendment in case involving nonrenewal of teacher's contract at state school).

24. To date, the interest in hife, as stated in the due process clause, has not been held to be affected in these cases.

25. 189 U.S. 86 (1903). Other courts have found that life, hiberty, and property interests are protected not only by the Constitution, but also by positive rules of law. See, e.g., Meachuin v. Fano, 427 U.S. 215, 226 (1976) ("[A] person's liberty is equally protected, even when the liberty itself is a statutory creation of the state."); Bishop v. Wood, 426 U.S. 341, 344 (1976) ("A property interest in employment can . . . be created by ordinance. . . ."); Goss v. Lopez, 419 U.S. 565, 572-73 (1975) ("Protected interests in property are normally . . created . . by an independent source such as state statutes or rules entitling the citizen to certain benefits."); Wolff v. McDonnell, 418 U.S. 539, 557 (1974) (when the state created the right to "good time," the prisoner's interest was well within fourteenth amendment liberty); Morrissey v. Brewer, 408 U.S. 471, 482 (1972) (parole system creates protected interest in continued liberty); Goldberg v. Kelly, 397 U.S. 254, 262 (1970) ("Relevant constitutional restraints apply ... to the withdrawal of public assistance benefits ...."). 
[T]his court has never held, nor must we now be understood as holding, that admimistrative officers, when executing the provisions of a statute involving the liberty of persons, may disregard the fundamental principles that inhere im "clue process of law" as understood at the time of the adoption of the Constitution. One of these principles is that no person shall be deprived of his liberty without opporturity, at some time, to be heard, before such officers, in respect of the matters upon which that hiberty depends .... . ${ }^{26}$

Cases that followed Japanese Immigrant reiterated this view. For example, in 1985, in Haitian Refugee Center v. Smith, ${ }^{27}$ the United States Court of Appeals for the Fifth Circuit found that the federal regulations establishing asylun procedures, ${ }^{28}$ as well as the United Nations Protocol that the United States signed in $1968,{ }^{29}$ created a liberty interest that protects refugees and asylum applicants. ${ }^{30}$ The court also found, in the fifth amendment's property clause, due process protections for Haitians and other refugees froin countries experiencing civil strife. ${ }^{31}$ The court agreed with the plaintiffs that the INS's accelerated deportation process and its knowing creation of scheduling conflicts and unattainable filing deadlines for Haitian apphicants violated the Constitution; the court einphasized that for the United States' commitnient to the United Nations Protocol to have any significance, the foreign-born at least inust be given the chance to seek political asyluin-even though the grant of asylum is ultimately discretionary. ${ }^{32}$ Indeed, the court noted that government conduct violates "the fundainental fairness which is the essence of due process when it creates a right . . . and then makes the exercise of that right utterly impossible."33 The court therefore ordered the INS to adhere to its established procedure-notice and a learing at a nieaningful time and in a meaningful manner. ${ }^{34}$

26. Japanese Immigrant Case, 189 U.S. at 100-01.

27. 676 F.2d 1023, 1028 (5th Cir. Unit B 1982).

28. 8 C.F.R. $\S 108$ (1980), repealed, 46 Fed. Reg. 45,118 (1981).

29. Protocol Relating to the Status of Refugees, Jan. 31, 1967, arts. 1, 32, 19 U.S.T. 6223, 6261, 6275, T.I.A.S. No. 6577, 606 U.N.T.S. 267. The Protocol prohibits the expulsion of any individual who has a "well-founded fear of being persecuted for reasons of race, religion, nationality, membership of a particular social group or political opinion." The individual can be excluded, however, on grounds of "national security or public order"-but due process must be met before expulsion is enforced. Haitian Refugee Center, 676 F.2d at 1028 n.8.

30. 676 F.2d at 1029. In Parker v. Cook, the court conceded that the government rarely labels its actions as creating "liberty interests," necessitating a judicial review of "the substance of the state action to determine whether a liberty interest has been created." 642 F.2d 865, 867 (5th Cir. Unit B 1981). Another court found that the President had "invited" tens of thousands of Cubans to this country and his invitation gave rise to a protected liberty interest that could not be impaired without due process of law. Fernandez-Roque v. Smith, 622 F. Supp. 887, 896-901 (N.D. Ga. 1985).

31. 676 F.2d at 1039.

32. Id. at 1038 .

33. Id. at 1040 .

34. Id. at 1038 . 
The Second Circuit's reasoning in Augustin v. Sava ${ }^{35}$ supports the Fifth Circuit's decision. Using a similar analysis, the Augustin court reasoned that by treaty, statute and regulations, the United States had inanifested its intention to hear pleas of aliens who claimed a fear of persecution in their hoinelands. ${ }^{36}$ The court noted that while this intention does not necessarily grant the privilege of asylum to all who enter the United States, it does grant the right to be heard on those pleas. Thus detainees have a constitutionally-protected right to petition and present an asyluin claim. ${ }^{37}$

\section{B. Deportation Proceedings.}

Even though a liberty or property interest has been created, a deportation hearing is only inandatory if due process will be denied when a hearing is not granted. The Supreme Court has created a balancing test to determine whether due process mandates a particular procedure. ${ }^{38}$ The factors considered under the test are (1) the private interests affected by the official action, (2) the "risk of an erroneous deprivation of [the private interests] through the procedures used, and the probable value, if any, of [the suggested] safeguard," and (3) the government interests affected by the suggested change, "including the . . . fiscal and administrative burdens that the [change] would entail." 39

Lower federal courts have used the Supreme Court's balancing test to find that various procedures followed by the INS did not ineet the minimum requirements mandated by the due process clause. In Haitian Refugee Center v. Smith, ${ }^{40}$ as discussed above, ${ }^{41}$ the Fifth Circuit held that the INS's accelerated deportation procedure denied due process to Haitian refugees. In applying the balancing test, the court found that (1) the Haitians had a strong interest in proving the entitlenicnt of asylum, (2) there was a high risk of erroneous determinations, and (3) the extra burden on the government was minimal, as the court only required adherence to established procedures..$^{42}$

35. 735 F.2d 32 (2d Cir. 1984).

36. Id. at 36-37; see Anker \& Rubin, The Right to Adequate Translation in Asylum Proceedings, 9 IMMigRaTion J., July-Sept, 1986, at 10, 19.

37. 735 F.2d at 37.

38. Mathews v. Eldridge, 424 U.S. 319, 335 (1976).

39. Id.; cf. Little v. Streater, 452 U.S. 1, 13 (1981).

40. 676 F.2d 1023 (5th Cir. Unit B 1982).

41. See supra notes $27-34$ and accompanying text.

42. 676 F.2d at 1040 . The court also noted without explication that "it is ... in the government's interest to make informed determinations." Id.; see also Augustin, 735 F.2d at 37-38 (noting that due process likely violated by failing to provide accurate translators in asyluin proceedings and that due process warrants hearings for aliens likely to be persecnted in their hoinelands). 
In Orantes-Hernandez v. Smith, ${ }^{43}$ a federal district court also found that INS procedures failed to satisfy due process. The court granted injunctive relief to prohibit the use of INS procedures that effectively coerced Salvadoran aliens into signing voluntary departure forms in lieu of requesting deportation hearings. ${ }^{44}$ The court found that INS agents disclosed only certain facts when the foreigners were decidiug whether to choose voluntary departure, einphasizing only the "down" side of the situation..$^{45}$ Although the court did not specifically use the balancing test in finding that the Salvadorans had been denied their constitutional and statutory rights, it did note that the risks to the Salvadorans froni denial of a deportation hearing outweighed any hardship to the INS. ${ }^{46}$ In dicta, the court used the balancing test as a secondary rationale for requiring that affirmative notice of the right to petition for asyluin be granted to the Salvadoran aliens. ${ }^{47}$

43. 541 F. Supp. 351 (C.D. Cal. 1982).

44. Id. at 374 .

45. Id. at 373 .

46. Id. at 374 .

47. Id. at 378 n.33. In 1984, the United States Court of Appeals for the Eleventh Circuit rejected the argument that due process inandates that excludable aliens receive notice of their right to apply for political asylum. Jean v. Nelson, 727 F.2d 957, 979, 982 (11th Cir. 1984), aff'd, 472 U.S. 846 (1985). The court's reasoning was three-fold. First, "Congress made no direct reference to a notice requirement"; second, "Congress provides many opportumities ... without requiring the governnent to publicize their availability," such as "the right to seek educational loans or public assistance"; and third, frivolous claims would be encouraged by informing all aliens of the right. 727 F.2d at 982-83.

Four members of the court filed a powerful dissent, reasoning that if the Act is "to have 'meaning' and the constitutionally proteeted right to petition for asylum ... is to have any substance, [the aliens] must be informed that the procedures and rights provided by the Act are available to them." Id. at 989-90. Moreover, notice would effectuate Congress's intent: Congress passed the Refugee Act to "give statutory meaning to our national conımitment to human rights and humanitarian concerns.' "Id. at 989 (quoting S. REl'. No. 256, 96th Cong., 2d Sess. 1, reprinted in 1980 U.S. CODE CONG. \& ADMIN. News 141). The dissent pointed out that it is riappropriate to liken this situation to one of educational loans and public assistance because the aliens that Congress hoped to aid by the Act "frequently arrive on our shores ignorant of our legal system and unschooled in our language." Id. at 989. Finally, the dissent noted that while it is true that fewer claims will be filed if aliens are not notified of their rights, those with legitimate claims will lose their right to petition, "effectively emasculating the very rights that Congress intended to create." Id. at 990 n.11.

Jean's applicability should be limited for two reasons. First, Jean concerned only the rights of excludable aliens-foreigners who, by a legal fiction that is applied during an "exclusion" hearing, may be kept from even entering the United States. See id. at 961 \& n.1. The aliens of concern in this cominent already have entered the country and are subjeet only to deportation. Second, according to the Supreme Court, the court of appeals improperly reached the constitutional question in Jean, as there were nonconstitutional statutory and regulatory grounds that shionld have been the basis for the decision. 472 U.S. 846, 848, 854 (1985) (proper grounds were the Immigration and Naturalization Act and the Naturalization Service Regulations).

In Ramirez-Osorio v. INS, the Fiftl Circuit held that the INS's refusal to give blanket notice of the right to petition for asylum frustrated neither congressional purposes nor the Constitution. 745 F.2d 937, 943 (5th Cir. 1984). Ramirez, however, was based on a criticism of previous cases that 


\section{Due Process Requires Mandatory Deportation Hearings for Unaccompanied Minor Aliens.}

When unaccompanied minor aliens are deprived of a deportation hearing, the resulting harm to their private interests is substantial and significant-_"during the formative years of childhood and adolescence, minors often lack the experience, perspective, and judgment to recognize and avoid choices that could be detrimental to them."48 Hence, when considering the legal interest of these unaccompanied children, one must heed the solicitude the law affords them. ${ }^{49}$ Indeed, application of the Court-created balancing test strongly supports the conclusion that deportation hearings inust be inandatory for unaccompanied minor aliens.

The first part of the test examines the private interests affected by the official action. These particular children have significant interests that are forfeited when they erroneously elect voluntary departure. Waiving the statutory right to a deportation proceeding results in the simultaneous waiver of numerous other statutory rights: for exanıle, representation by counsel, examination of adverse evidence, presentation of exculpatory evidence and cross-examination of witnesses. ${ }^{50}$ These rights can hardly be deemed insignificant.

Unaccompanied children also have substantial interests in the many alternatives available under the Act: pohitical asylum, ${ }^{51}$ withholding of deportation, ${ }^{52}$ adjustment of status, ${ }^{53}$ suspension of deportation, ${ }^{54}$ and deferred action status. ${ }^{5 s}$ Not surprisingly, the United States District

had failed to counterbalance administrative necessity in making the determination that due process required blanket notice of a constitutional right. Id. at 945-46. Thus, Ramirez should be limited to cases in which "the additional administrative burdens that might result" outweigh the benefit that would ensue from the change in procedure. Id. at 946. Indeed, Ramirez itself recognizes the necessity of giving notice to "high risk populations," id. at 947 , which certainly defines the unaccompanied alien children at issue here.

48. Bellotti v. Baird, 443 U.S. 622,635 (1979); see also Eddings v. Oklahoma, 455 U.S. 104, $115-16,116 \mathrm{n} .12$ (1982) (recognizing, in criminal law context, that youth "is a time and condition of life when a person may be most susceptible to influence"); Parham v. J.R., 442 U.S. 584, 603 (1979) (noting, in mental health context, that "[m]ost children, even in adolescence, simply are not able to make sound judgments concerning many decisions").

49. See In re Gault, 387 U.S. 1, 16-17, 30 (1967) (discussing special policy of parens patriae applied to mmors); Kent v. United States, 383 U.S. 541, 550 (1966) (same).

50. See supra notes 18-21 and aceompanying text (discussing statutory right to deportation hearings).

51. 8 U.S.C. $\$ 1158$ (1982).

52. Id. $\S 1253(\mathrm{~h})$.

53. Id. § 1254(a).

54. Id.

55. See Nicholas v. INS, 590 F.2d 802 (9th Cir. 1979) (discussing Immigration and Naturalization Service Operating Instruction 103.1(a)(1)(iii) (1978), which authorized district director to grant status deferring deportation indefinitely for humanitarian reasons). The current operating instruction, 103.1(a)(1)(ii) (1981), which superseded the 1978 instruction, seriously undermines the ration- 
Court for the Central District of California agrees that minors' constitutional rights are deprived when they waive their right to a deportation hearing because they do not understand the panoply of rights their waiver abandons:

it is a reasonable conclusion that many unaccompanied minors consent to voluntary departure without knowledge that there are other alternatives available. . . . Having determined that most . . . waive rights which they could not know of when they consent to voluntary departure, it follows that these waivers of rights, because they are not made voluntarily, intelligently, and knowingly, are ineffective [and effect] a de facto deprivation of these minors' constitutional rights. ${ }^{56}$

The second part of the test, which considers the harm resultimg from the government procedure and the benefits ensuing from the suggested safeguards, also weighs in favor of the proposed change. Under current INS procedures, the risk of erroneous results-that is, returning a child who has a legitimate clain to remain in the United States-is great. Reasonable consideration of the age, experience, educational level, intelligence and cultural and language background of these children ${ }^{57}$ suggests that unaccompanied minor aliens understand neither the INS forni, the nature of their rights, nor the consequences of exercising or waiving those rights. Thus, the risk of error is both substantial and likely. Moreover, the benefits that would result from implementing the suggested change-mandatory deportation hearings for all unaccoinpamed minors-are manifest.

The third part of the balancing test examines the government interests affected by the suggested change. Concerns with administrative effciency and ensuring greater comphiance with constitutional and statutory commands ${ }^{58}$ suggest that mandating deportation hearings for these children is actually in the government's interest. Mandatory deportation hearings are likely to increase governmental efficiency and ensure greater procedural compliance by alleviating the sporadic and uncertain efforts occasionally taken by the INS to inject fairness into the deportation process. The INS is hampered both by language difficulties between the

ale in Nicholas. Romeiro De Silva v. Smith, 773 F.2d 1021, 1024 (9th Cir. 1985). Indeed, the new instruction has been viewed as conferring no rights on aliens; instead, it operates " 'merely for the INS's own convenience." 'Id. (quoting Sivcrts v. Craig, 602 F. Supp. 50, 53 (D. Haw. 1985)).

56. Perez-Funez v. INS, 611 F. Supp. 990, 1002-03 (C.D. Cal. 1984).

57. See Fare v. Michael C., 442 U.S. 707, 725 (1979) (Authorities must take into account "those special concerns that are present when young persons, often with limited experience and education and with immature judgment, are involved.").

58. Orantes-Hernandez v. Smith, 541 F. Supp. 351, 374 (C.D. Cal. 1982); cf. Goldberg v. Kelly, 397 U.S. 254, 264-65 (1970) (finding government interest in affording hearing before termination of welfare benefits because it would foster commitment to "dignity and well-being of all persons within its borders"). 
Border Patrol agents and the detained children" and by the "legal language" of the rights. Some Border Patrol agents repeatedly rephrase the wording of the statements of rights in response to the children's questions about the legal words and concepts. ${ }^{60}$ Hence, the nature of the "explanation given, if any, depends upon the individual agent and circumstances at the time of interrogation." 61

The suggested change, requiring deportation hearings for all unaccompanied minor aliens, will not place undue strani upon the courts. The new process will apply only to unaccompanied minors-the most vulnerable of all. Even if a strain on the court system does develop, any administrative burden is clearly outweighed by the private interests at stake. 62

\section{Psychological Data}

Psychological research supports the conclusion that detained children cannot make a knowing, intelligent, and voluntary waiver of their legal rights. In one recent study, for exaniple, Thomas Grisso found that a majority of American juveniles were not coinpetent to waive their Miranda rights. ${ }^{63}$ Although Miranda rights apply only in criminal proceedings and not in the deportation context, the results of Grisso's research are still instructive, for they suggest that the majority of juveniles-even those who are native Enghish speakers-cannot knowingly, intelligently, and voluntarily waive any legal rights, whether civil or criminal.

59. Spanish is the only language of the vast majority of the minor aliens. While some INS Border Patrol agents speak native Spanish, many have taken no courses in the language other than the 19-week training course at the Border Patrol Academy. Plaintiffs' Brief, supra note 2, at 5 n.1.

60. Id. at 4-5. The terms that are frequently misunderstood include: "deportation hearing," "bail," "voluntary departure," and "asylum." Id.

61. Id.

62. Cf. Goldberg, 397 U.S. at $265-66$ (finding that in the welfare context increased fiscal and administrative burden is outweighed by private interests of recipients).

63. T. Grisso, Juveniles' WaIVER of Rights: Legal and Psycholggical CoMpetence 59-88 (1981). Grisso's "resnlts indicate that understanding [of the Miranda rights] is indeed deficient in [the twelve or below] age range compared to the overall juvenile sample, with madequate understanding present in about three of four cases in this age range (compared to about one of two for the total sample)." Id. at 89. His resnlts also show, however, that between the ages of fourteen and sixteen "age itself ceased to account for individual differences in understanding." Id. at 90. Thus, Grisso recommends that, while age and intelligence shonld serve as "legal indicants" in determiming a juvenile's ability competently to waive her legal rights, intelligence should weigh more heavily in later teenage years. Id.

One may infer from Grisso's finding of the decreased significance of age between the ages of fourteen and sixteen that "intelligent" older minors wonld have a greater understanding of their legal rights than would less intelligent minors. This reasoning, however, is inapplicable to the present inquiry; even an intelligent older minor in Mexico or El Salvador, for example, and even one who is hiterate in English, would be unfamiliar with American legal institutions and would necessarily still have difficnlty understanding American legal rights. 


\section{A. Can Juveniles Knowingly Waive Miranda Rights?}

Grisso examined the ability of juveniles to comprehend Miranda rights. He assumed that if the rights are understood, then the element of "knowing," as required by the fifth amendment in cases of waiver, is fulfilled. ${ }^{64}$ Grisso used three methods to determine whether the juveniles understood the Miranda rights. First, he asked the juveniles to paraphrase the warnings after they heard them read aloud and saw them displayed on printed cards. ${ }^{65}$ The results of this method showed that only $20 \%$ understood all four Miranda warnings; $55 \%$ misunderstood at least one warning, and the remaining $25 \%$ had only "questionable" understanding of the warnings. ${ }^{66}$

Grisso next asked the juveniles to define key words in the Miranda warnings; he assuined that even a seemingly accurate paraphrase could conceal misconception if the subjects had not understood the important words in the warning. ${ }^{67}$ In this instance, six key words of the Miranda warnings were read to the juveniles, who then saw the same words displayed on printed cards. ${ }^{68}$ After listening to a sentence usmg one of the words, the juveniles were asked to explain what the word meant. ${ }^{69}$ Nearly two-thirds of the juveniles misunderstood at least one of the six words. ${ }^{70}$

Finally, Grisso asked the juveniles to identify and match preconstructed sentences with meanings similar to those found in the warnings. Again, a Miranda warning was shown and read to the juveniles. The juveniles were then asked to determine whether other sentences that were read aloud by the examiners liad meanings similar to the Miranda warnings. ${ }^{71}$ In this, as in the first measure, the juveniles demonstrated an inadequate understanding of their right to have an attorney before and during interrogation; their understanding of their right to have an attorney appointed was even poorer than it was in the first measure. ${ }^{72}$ Indeed, approximately $30 \%$ of the juveniles answered incorrectly in at least one of three cases. ${ }^{73}$

64. T. GRISSO, EVAlUating COMPETENCIES: ForENSIC ASSESSMENTS AND INSTRUMENTS 114-18 (1986).

65. T. GRISSO, supra note 63 , at $43-51$.

66. Id. at 73,74 table 6 .

67. Id. at 51 .

68. Id. at 51-52. The six words used were "consult," "attorney," "interrogation," "appoint," "entitled," and "right." Id.

69. Id. at 52 .

70. Id. at 75-77.

71. Id. at 51 .

72. Id. at 78 table 8.

73. Id. 
Drawing from the results of all three methods of determining competency, Grisso concluded that about half of the juveniles aged ten to sixteen misunderstood at least one of the Miranda rights. ${ }^{74}$ This misunderstanding was significantly higher among those under the age of fourteen. ${ }^{75}$ The results speak for themselves: overwhelmingly, juveniles cannot knowingly waive their Miranda rights.

\section{B. Can Juveniles Intelligently Waive Miranda Rights?}

To test the ability of juveniles to intelligently waive Miranda rights, Grisso studied the juveniles' nnderstanding of the purpose and function of these rights. ${ }^{76} \mathrm{He}$ assumed that competence to waive a right requires not only an understanding of the right, but also an understanding of its significance. ${ }^{77}$ Indeed, in the Miranda setting, if a defendant lacks this understanding, a court is not justified in ruling that a waiver is valid. ${ }^{78}$ Thus, Grisso measured comprehension of the significance of the right to remain silent, the function of defense attorneys, and the role of police in interrogation. ${ }^{79}$

Not surprisingly, the research demonstrated that many juveniles do not understand the significance of the right to remain silent. One-third believed that defense attorneys defend only the innocent. ${ }^{80}$ Many beheved that a pohice officer could lawfully persuade a person not to remain silent, and "a majority ... beheved that a judge could revoke a person's right" to remain silent. ${ }^{81}$ Based on these misconceptions, a waiver of the right to remain silent and the right to counsel cannot be considered intelligent.

Grisso also explored the way juveniles decide whether or not to waive their rights..$^{82}$ Here, when presented with hypothetical questions, the juveniles under fourteen years old considered fewer alternatives, fewer possible consequences, and more immediate than long-range consequences. ${ }^{83}$ The same conclusion held for the juveniles of a distinct cultural minority (in this case blacks). ${ }^{84}$

74. Id. at 192.

75. Id.

76. Id. at $109-30$.

77. Id. at 109.

78. See Brewer v. Williams, 430 U.S. 387,404 (1977).

79. T. GRISSo, supra note 63 , at $110-12$.

80. Id. at 129.

81. Id.

82. Id. at $131-60$.

83. Id. at $157-60$.

84. Id. 


\section{Can Juveniles Voluntarily Waive Miranda Rights?}

To determine whether juveniles exercise their rights without inhibition and thus act voluntarily when making waiver decisions, Grisso compiled data on how frequently the juveniles invoked the right to remain silent. ${ }^{85} \mathrm{He}$ assumed that if adults exercised this right significantly more than did children, the children's inhibition would be attributable to lack of voluntariness. ${ }^{86}$ In the jurisdiction studied, approximately threequarters of the juvemiles who were arrested for felomious crimes were imterrogated by police, but only about $10 \%$ of them asserted their right to remain silent. ${ }^{87}$ Moreover, children under fifteen almost never exercised the right to remain silent, whereas adults asserted the right in $42.7 \%$ of the cases. ${ }^{88}$ In addition, while a majority of juveniles suggested obtaining legal counsel in response to hypotheticals about interrogation and waiver, once arrested very few actually requested lawyers. ${ }^{89}$ This study presents even stronger evidence that juveniles are inhibited in the exercise of their rights. Thus, their actions cannot be truly voluntary. 90

In sum, Grisso's research revealed that American juveniles under fourteen are overwhelmingly unable to knowingly, intelligently, and voluntarily waive their legal rights.91 Even without further empirical research, one would expect that foreign-born children, necessarily froin a distinct culture, would also have difficulty understanding their legal rights.

In fact, foreign children are at an even greater disadvantage. First, unlike most American children, foreign-born juveniles generally are not fluent in English. Second, American legal institutions (such as courts and hearings) and the freedoms that America grants are unfamiliar to many foreign-born children. Because a majority of American juveniles cannot make a knowing, intelligent, and voluntary waiver of their Miranda rights, ${ }^{92}$ it is inconceivable that foreign children, not ouly suffermg

85. Id. at $25-39$.

86. Id. at 25-26.

87. Id. at 38.

88. Id. at 25, 38, 191 (citing Seeburger \& Wettick, Miranda in Pittsburgh: A Statistical Study, 29 U. PITT. L. REv. 1 (1967)).

89. Id. at $192-93$.

90. High rates of obedience and comphance among children, especially adolescents aged 11-14, also have been documented. Id. at 26 (citing Constanza \& Shaw, Conformity as a Function of Age Level, 27 ChILd DEv. $967-75$ (1966); Patel \& Gordon, Some Personal and Situational Determinants of Yielding to Infiuence, 61 J. ABNoRMal \& Soc. PsYch. $411-18$ (1960)). Another researcher developed characteristics that correlate with higher rates of complance. See id. at 25 (citing Driver, Confessions and the Social Psychology of Coercion, 82 HARV. L. Rev. $42-61$ (1968)). While adults possess some of these qualities in varying degrees, juveniles characteristically possess more of them.

91. T. GRISSO, supra note 63, at 191-94.

92. Id. 
the difficulties of youth, but also unfamiliar with both the American judicial process and the English language, can make a knowing and intelligent waiver of similar legal rights. The ouly logical alternative, then, to protect the interests of these children, is to afford all unaccompanied minor aliens deportation hearings.

While a deportation liearing provides no assurance that a foreigner will be afforded all protections available under the law, certainly counsel at a hearing would diligently represent his or her chent. Even without the benefit of counsel, however, the immigration judge is duty-bound to uphold all laws and follow the Constitution. ${ }^{93}$ Thus, there is little doubt that a foreigner is much more likely to be adequately protected by American laws if granted a deportation hearing than if denied one.

Some critics will suggest that if the INS waiver were merely reworded or a translator were provided, then the problems with the current procedures would be remedied. Two other studies on Miranda rights and juveniles suggest, however, that these measures would be wholly inadequate. ${ }^{94}$ Both studies demonstrate that simplifying the Miranda warnings does not result in greater understanding. ${ }^{95}$ Similarly, even a better understandimg of the INS form would not necessarily result im a fully valid waiver. Grisso's research estabhishes that merely understand$\mathrm{mg}$ the words on a form does not demonstrate that one understands the significance of those words. ${ }^{96}$ For example, understandimg that Miranda afforded a general right to silence, but beheving that the right could be revoked, strongly illustrates a "failure to sense the legal protection behind the right."97 Misconceiving the right as conditional would result in an invalid waiver.

Likewise, merely providing a translator would not ensure a knowing, intelligent, and voluntary waiver of the right to a deportation hearing. While translation may help provide a better understanding of the spoken words, again it would not ensure that the detained children would understand the significance of those words. Because Americanborn children suffer such grave difficulties understanding their legal rights, the logical assumption is that foreign youngsters' potential difficulties are even greater.

93. 28 U.S.C. $\S 453$ (1982).

94. See T. GRISso, supra note 63, at 197 (citing Ferguson \& Douglas, A Study of Juvenile Waiver, 7 SAN Diego L. Rev. 39-54 (1970); S. Manoogian, Factors Affecting Juveniles' Comprehension of Miranda Rights (1978) (unpublished doctoral dissertation, St. Louis University)).

95. Id. While not ruling out the possibility that a certain rewording would be better understood, the researchers questioned whether "any single rewording of the warnings would suffice, given the wide range of cultural, linguistic, and educational backgrounds of juvenile suspects." II.

96. Id. at $109-30$.

97. Id. at $128-29$. 


\section{CONCLUSION}

The inability of unaccoinpanied minor aliens to understand their legal rights is particularly clear when one contrasts the very different social and political experiences of most aliens with that of most Americans. Early experiences have taught many aliens not only to mistrust governments, but also to fear thein. Once arrested in this country, these sanie aliens are herded into detention ccnters. Unaccompanied minor aliens, who typically are unable to speak English, ignorant of the American system, and undoubtedly frightened, will certainly choose the option they perceive the adult in charge wants them to choose when they are asked to decide between voluntary departure and a deportation hearing. ${ }^{98}$ Thus, their "choice" is not only involuntary, it is really no choice at all.

When waiving a deportation hearing after being apprehended by INS Border Patrol Agents, these unaccompanied children undoubtedly fail to consider the myriad of rights they waive in addition to that of a deportation hearing. If deportation hearings were to become mandatory for these children, those who would have waived a constitutional right to a hearing and all that is consequent to that right, those who would have waived statutory rights to apply for political asylum, suspension of deportation, refugee status, and adjustment of status, and those who may have been returned to a land hostile towards them would be permitted to exercise their due process rights and be protected as American law prescribes. The value of this safeguard is immeasurable; it is the value of life itself.

98. See Plaintiffs' Brief, supra note 2 , at 8. 